\title{
Forecasting the Effects of Land-Use and Climate Change on Wildlife Communities and Habitats in the Lower Mississippi Valley
}

\section{Introduction}

Landscape patterns and processes reflect both natural ecosystem attributes and the policy and management decisions of individual Federal, State, county, and private organizations. Land-use regulation, water management, and habitat conservation and restoration efforts increasingly rely on landscape-level approaches that incorporate scientific information into the decisionmaking process. Since management actions are implemented to affect future conditions, decision-support models are necessary to forecast potential future conditions resulting from these decisions (Starfield, 1997). Spatially explicit modeling approaches enable testing of different scenarios (Provencher and others, 2007) and help evaluate potential outcomes of management actions in conjunction with natural processes such as climate change (Johnson and others, 2010). The ability to forecast the effects of changing land use and climate is critically important to land and resource managers since their work is inherently site specific, yet conservation strategies and practices are expressed at higher spatial and temporal scales that must be considered in the decisionmaking process.

\section{Land-Use Change}

The Lower Mississippi Valley is the largest flood plain in the United States, extending from southern Missouri and Illinois to the northern Gulf of Mexico. The 10-million-hectare area encompasses parts of seven States with a drainage basin exceeding 40 percent of the continental United States. The forests of the Lower Mississippi Valley have been converted to other land uses, primarily agriculture, resulting in the loss of more than 75 percent of the riparian forests, with only highly fragmented patches remaining (fig. 1) (MacDonald and others, 1979; Hefner and Brown, 1985). Despite these landscape-scale changes, the area provides critically important ecosystem services, including food, fiber, and ecological carbon sequestration. The Lower Mississippi Valley also provides habitat for several threatened or endangered species, including the Louisiana black bear (Ursus americanus luteolus) (Neal, 1992), as well as globally critical migratory bird habitat (Pashley and Barrow, 1993).

Large-scale efforts are underway to restore former riparian habitats on both public (Federal wildlife refuges, State lands) and private lands. More than 25,000 hectares of national wildlife refuges in the valley have been reforested with many projects related to carbon storage. Land-use practices associated with U.S. Department of Agriculture conservation programs (for example, Wetland Reserve Program [WRP], Conservation Reserve Program [CRP], Wildlife Habitat Incentive Program [WHIP], and so on) have been implemented since 1992, and the WRP has become the major program for afforestation of forested wetlands within the valley (Schoenholtz and others, 2001; Faulkner and others, in press). The combined actions of the conservation programs have resulted in about 180,000220,000 hectares of bottomland hardwood afforestation (Haynes, 2004).

\section{Climate Change}

There is scientific evidence that rising concentrations of greenhouse gases (GHGs) are causing changes to climate worldwide with adverse effects on ecosystems, hydrology, and natural resources (Rosenzweig and others, 2007). Terrestrial carbon sequestration through afforestation of marginal cropland is an important carbon dioxide $\left(\mathrm{CO}_{2}\right)$ mitigation strategy in the Lower Mississippi Valley (fig. 2). Despite this and other nationwide programs, current sequestration efforts alone are not capable of reducing or stabilizing atmospheric $\mathrm{CO}_{2}$ concentrations over the next 100 years (Sundquist and others, 2008). Regardless of GHG scenarios or climate mitigation efforts, climate-change impacts will cascade through biogeochemical and hydrologic processes and ultimately impact ecosystem structure, function, and services for at least several more decades.

The forests and wetlands of this flood plain are particularly susceptible to hydrologic alterations caused by climate change, which has the potential to severely impact vulnerable ecosystems throughout this large area. Understanding the interactive effects of land-use change and climate change on the sustainability and vulnerability of Lower Mississippi Valley ecosystems and their biota is critically important to not only the Department of the Interior but also other Federal and State agencies and nongovernmental organizations with significant resource management and conservation responsibilities. These agencies and organizations are currently implementing management decisions in the Lower Mississippi Valley to achieve specific goals for ecosystem services, such as restoring and conserving wildlife populations or implementing carbon sequestration, under the assumption that current conditions will persist. 


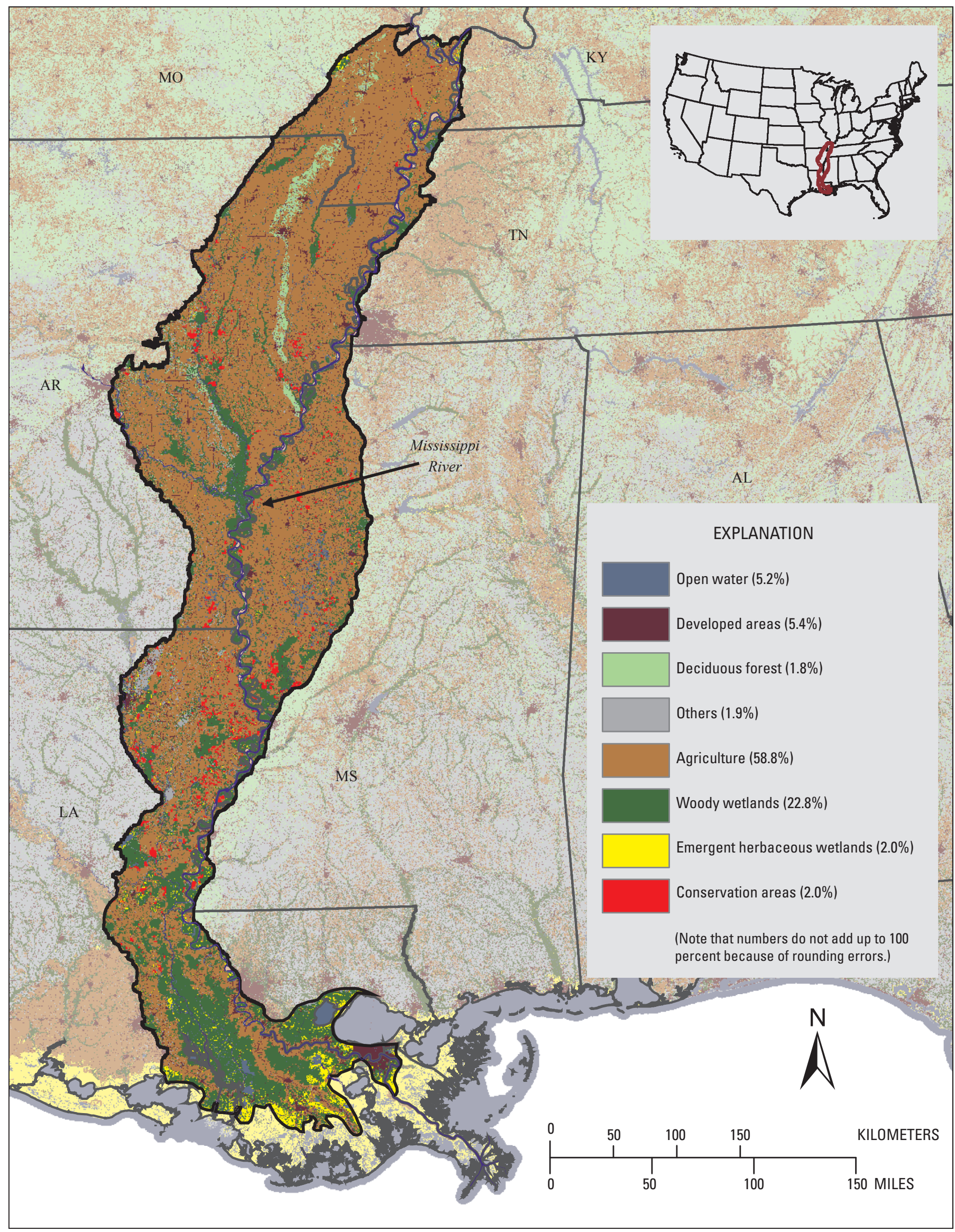

Figure 1. Geographic extent, land use, and land cover of the Lower Mississippi Valley (modified with permission from Faulkner and others, in press). 

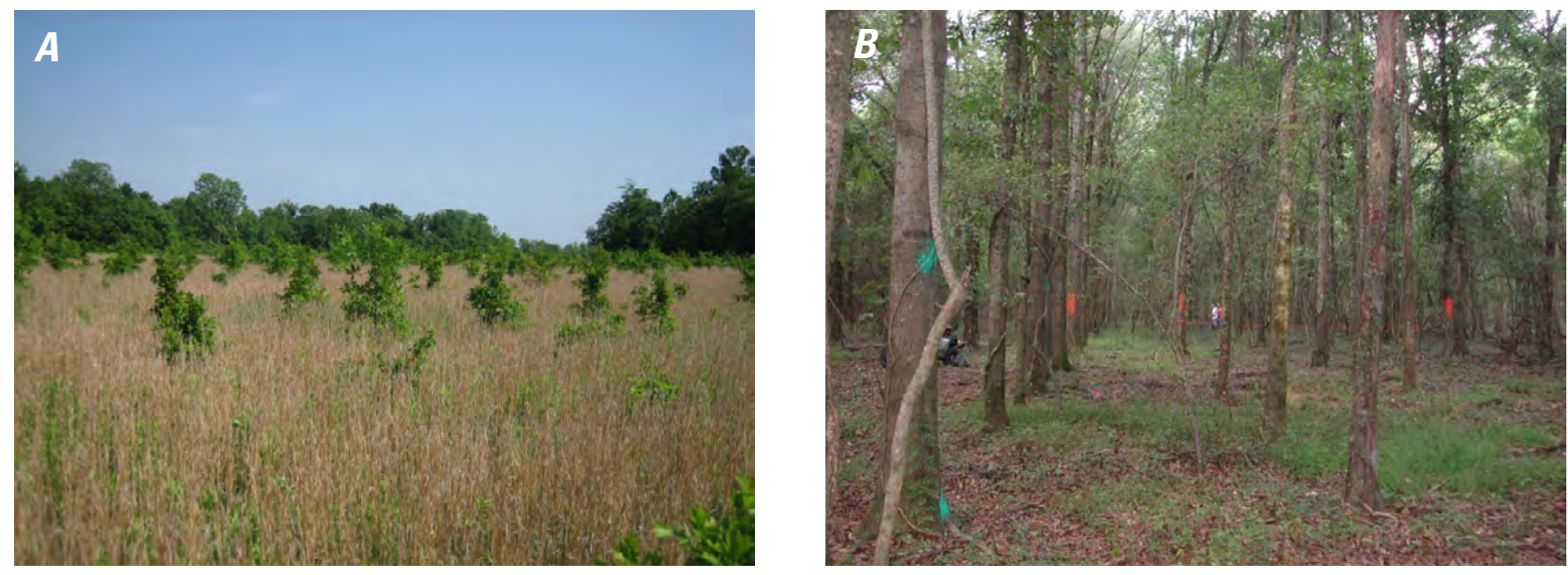

Figure 2. Afforestation of marginal cropland designed to restore wildlife habitat and sequester carbon. $A$, Recently planted trees. $B, A 30$-year-old stand marked for research on carbon cycling.

\section{Research Approach To Understanding and Forecasting Changes}

Understanding potential impacts of climate change on Federal trust resources and species and the sustainability and vulnerability of ecosystems that support them is a priority science need. Addressing this science need requires answering two fundamental questions:

1. What are likely future climate conditions?

2. How will these conditions affect functions and processes controlling ecosystem structure and services?

To answer these questions, we are employing a multidisciplinary research approach in collaboration with our regional conservation partners (see text box) that specifically addresses hydrologic and ecological forecasting, adaptation, and thresholds of climate change for ecosystems of the Lower Mississippi Valley and their services. The objectives of this work are to

- assess and quantify impacts of climate change on watershed hydrology, forest, and wetland ecosystems within the Lower Mississippi Valley,

- estimate the vulnerability of these systems to detrimental climate-change impacts,

- quantify impacts on terrestrial carbon sequestration,

- develop needed decision-support systems, and

- identify assessment and monitoring approaches.

We have quantified specific temperature and precipitation scenarios for the Lower Mississippi Valley through statistical downscaling of existing global circulation models (fig. 3) to explore spatially explicit changes in the hydrologic regime at the watershed and basin scales (with the Soil and Water
Multidisciplinary Regional Conservation Partners and Expertise

\section{U.S. Geological Survey}

- National Wetlands Research Center/Leetown Science Center: ecosystem services, old-growth forests, Neotropical migratory birds, forest and landscape modeling, hydrologic modeling, amphibian ecology

- Louisiana Water Science Center: water quality, hydrodynamics, sedimentation

- National Research Program: flood plain geomorphology, sedimentation

\section{U.S. Fish and Wildlife Service}

- Lower Mississippi Valley Joint Venture: avian ecology, habitat suitability modeling

- Baton Rouge Fish and Wildlife Conservation Office: water quality, fisheries habitat, resource management

Ducks Unlimited, Inc.: waterfowl ecology

Louisiana Department of Wildlife and Fisheries: wildlife habitat, restoration, management action plans 
$\boldsymbol{A}$

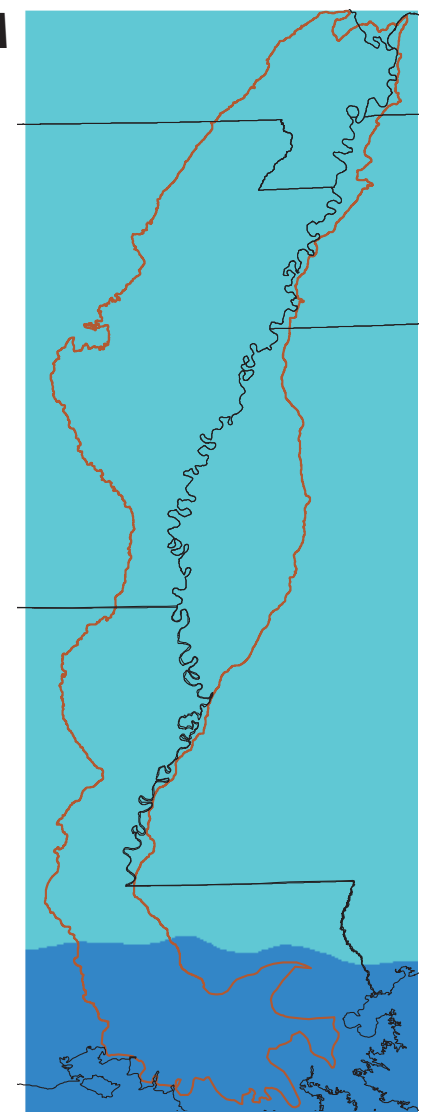

$\boldsymbol{B}$

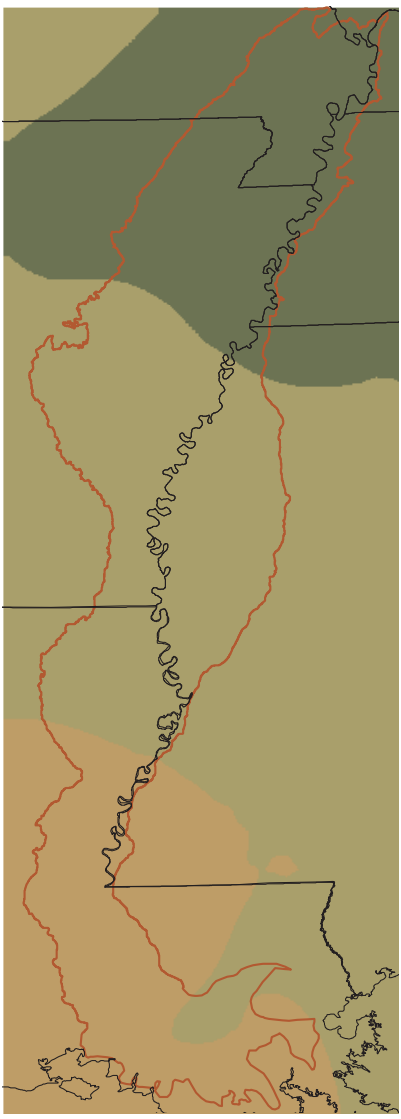

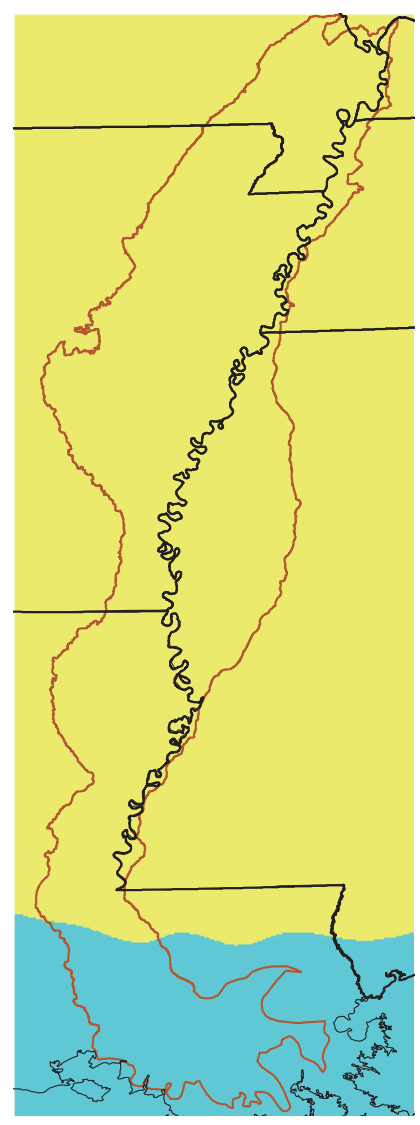
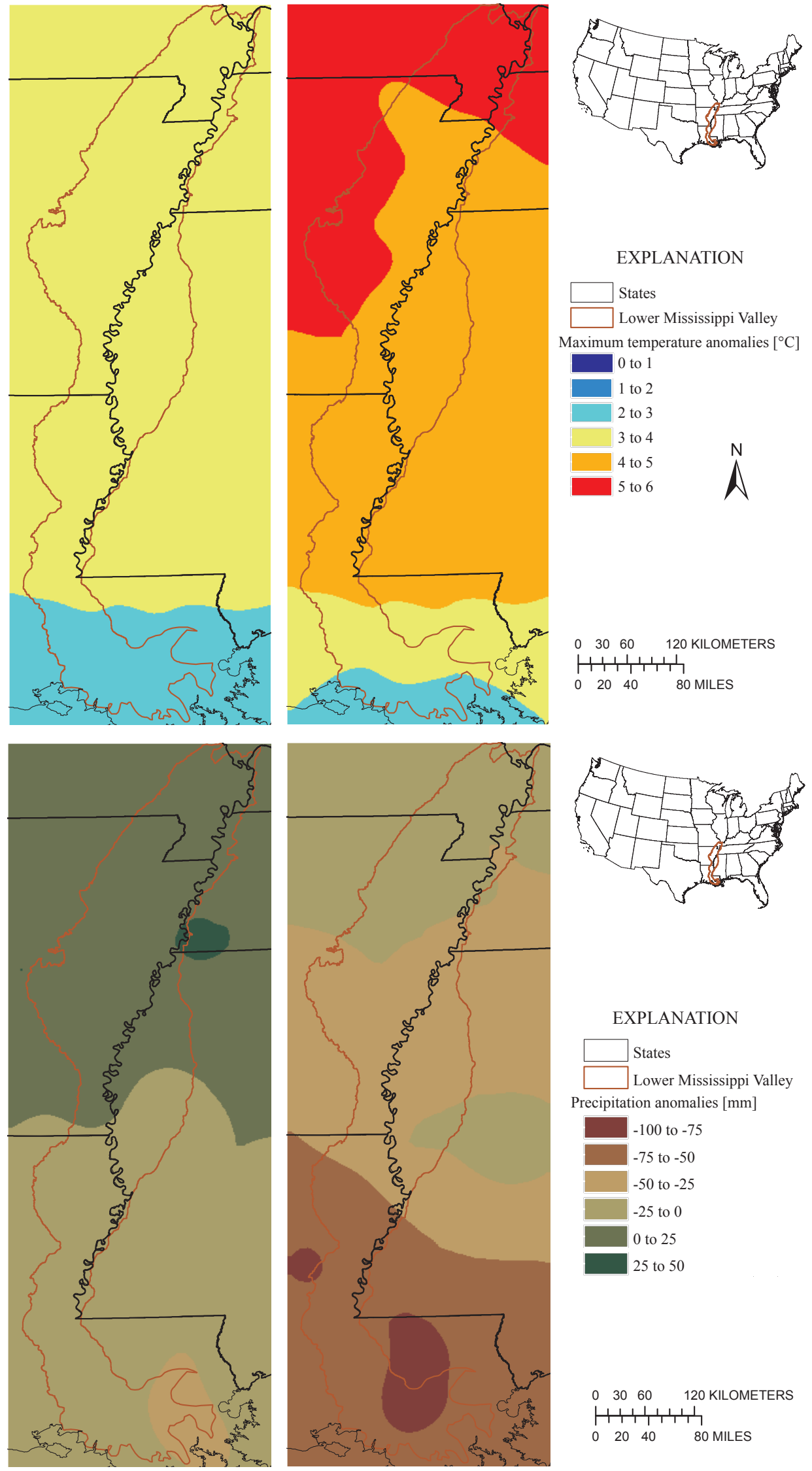

$0 \quad 3060 \quad 120$ KILOMETERS

HبTh

$\begin{array}{llll}0 & 20 & 40 & 80 \text { MILES }\end{array}$
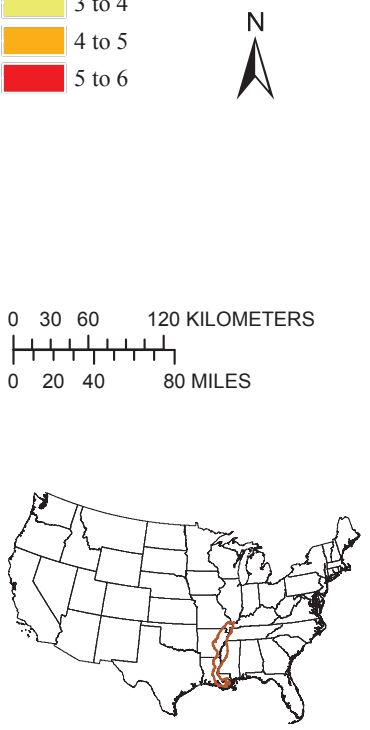

EXPLANATION

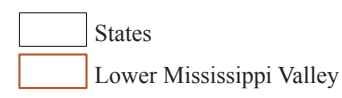

Precipitation anomalies $[\mathrm{mm}]$

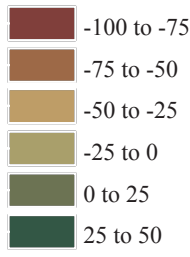

H.TH

$\begin{array}{llll}0 & 20 & 40 & 80 \text { MILES }\end{array}$ \begin{tabular}{llll}
0 & 30 & 60 & 120 KILOMETERS \\
\hline & + & + & +
\end{tabular}

Figure 3. Climate changes during June, July, and August for Intergovernmental Panel on Climate Change (IPCC) Special Report on Emissions Scenarios (Nakicenovic and others, 2000) climate-change scenarios A2, A1B, and B1 in 2095 compared to current climate conditions in the Lower Mississippi Valley. A, Changes in maximum temperature, in degrees Celsius. $B$, Changes in average precipitation, in millimeters. 
Assessment Tool [SWAT] and Precipitation-Runoff Modeling System [PRMS] models). We are using summary data and model outputs at the appropriate scales to assess the effects of climate change on forest growth and structure (with the LANDIS II model), carbon sequestration, sediment and nutrient retention, ecosystem flow requirements, and habitat sustainability for amphibians, migratory birds, fisheries, and waterfowl (with statistical and habitat suitability index [HSI] models).

\section{Forecasting Products and Activities}

Anticipated products will include spatially explicit estimates of future habitat conditions and abundance estimates based on expected climate change over a range of management actions, as well as models that predict amphibian community composition and species occurrence under different climate scenarios. We are developing a frame-based ecosystem services model to quantify the effects of changes in land use, land cover, and climate on important ecosystem services, including wildlife habitat (bird species richness, duck energy days, amphibian occupancy rates), climate regulation (carbon sequestration), and water quality (potential nitrate retention) simultaneously (fig. 4). The model structure and the user interface are designed to provide a flexible framework for resource managers and decisionmakers to evaluate whether current management strategies and conservation practices will result in the projected and desired outcomes in the Lower Mississippi Valley.

A
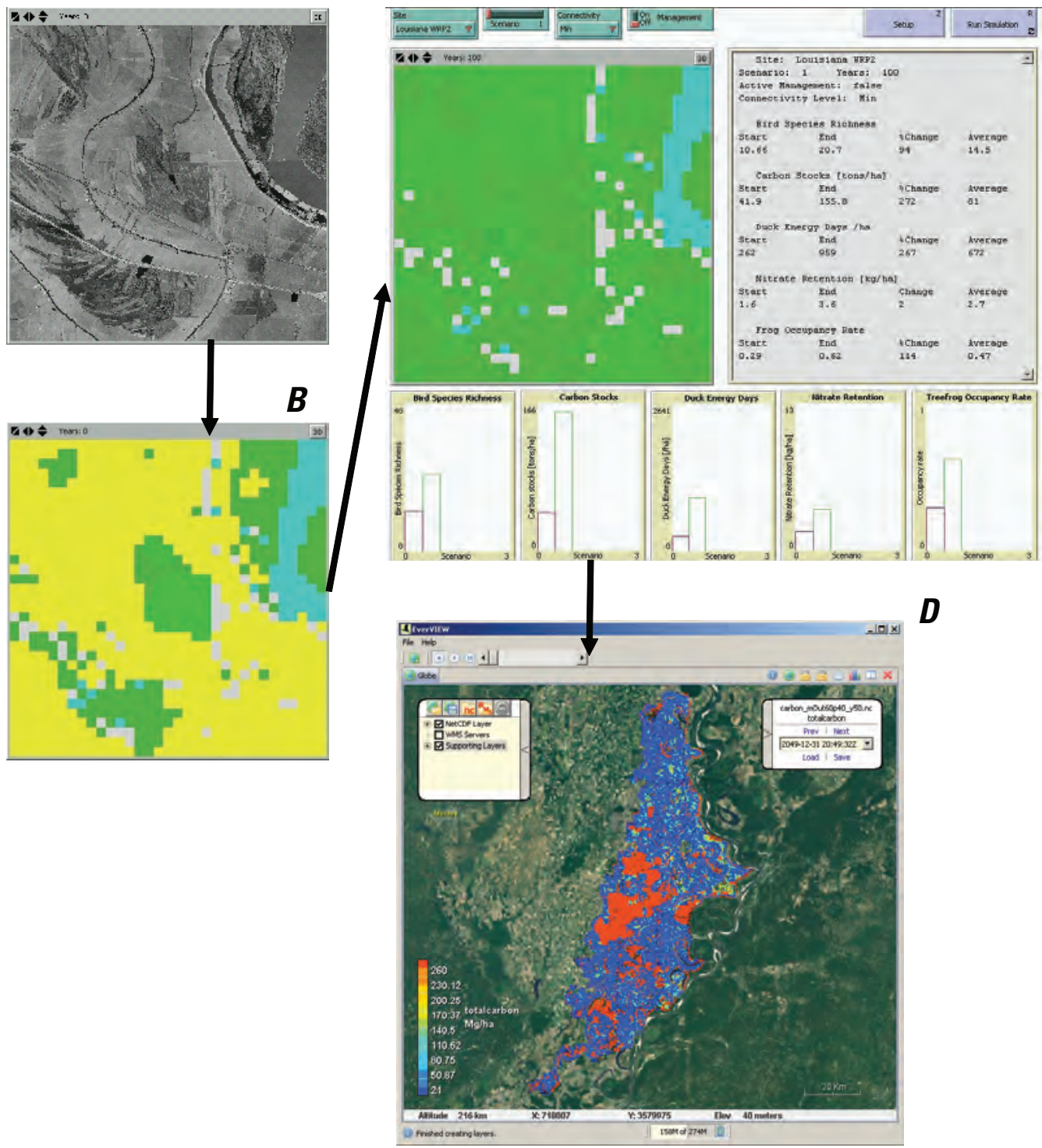

Figure 4. Graphic examples of the user interface for the ecosystem services model being developed. $A$, An original 10- by 10-km landscape from a digital orthophoto quarter quadrangle (D000) image. $B$, The D000 image converted to a digitized version with cropland (yellow), restored forest (light green), natural forest (dark green), and water (blue) pixels within the model window. $C$, Following a 100-year model run in which cropland is converted to restored forests, numerical and graphical outputs reflect changes from initial (time zero) conditions in ecosystem service metrics. $D$, Additional spatially explicit outputs of individual services like carbon sequestration. 
We will convene a workshop cosponsored by the U.S. Geological Survey and the Lower Mississippi Valley Joint Venture, in association with the Gulf Coastal Plains and Ozarks Landscape Conservation Cooperatives, for resource managers, decisionmakers from State and Federal agencies, and nongovernmental organizations. The purpose of the workshop will be to present project results and relevant decision-support tools; recommend monitoring approaches; solicit feedback; and identify future collaborative efforts to evaluate, mitigate, and adapt to impacts from land-use change and climate change in the Lower Mississippi Valley.

\section{References Cited}

Faulkner, S.P., Barrow, W.C., Jr., Keeland, B., Walls, S., and Telesco, D., in press, Effects of conservation practices on wetlands in the Mississippi Alluvial Valley: Ecological Applications.

Haynes, R.J., 2004, The development of bottomland forest restoration in the lower Mississippi Alluvial Valley: Ecological Restoration, v. 22, p. 170-182.

Hefner, J.M., and Brown, J.D., 1985, Wetland trends in the southeastern United States: Wetlands, v. 4, p. 1-11.

Johnson, W.C., Werner, B., Guntenspergen, G.R., Voldseth, R.A., Millett, B., Naugle, D.E., Tulbure, M., Carroll, R.W.H., Tracy, J., and Olawsky, C., 2010, Prairie wetland complexes as landscape functional units in a changing climate:

BioScience, v. 60, p. 128-140.

MacDonald, P.O., Frayer, W.E., and Clauser, J.K., 1979, Documentation, chronology, and future projections of bottomland hardwood habitat loss in the lower Mississippi Alluvial Plain, v. 1, Basic Report: Washington, D.C., U.S. Fish and Wildlife Service, Ecological Services.

Nakicenovic, N., Alcamo, J., Davis, G., de Vries, B., Fenhann, J., Gaffin, S., Gregory, K., Grübler, A., and others, 2000, Special report on emissions scenarios - a special report of Working Group III of the Intergovernmental Panel on Climate Change [IPCC]: Cambridge, U.K., Cambridge University Press, 599 p.

Neal, W.A., 1992, Threatened status for the Louisiana black bear: Federal Register, v. 57, no. 4, p. 588-595.

Pashley, D.N., and Barrow, W.C., Jr., 1993, Effects of land use practices on Neotropical migratory birds in bottomland hardwood forests, in Finch, D.M., and Stangel, P.W., eds., Status and management of Neotropical migratory birds. General Technical Report RM-229: Fort Collins, Colo., U.S. Department of Agriculture, U.S. Forest Service, Rocky Mountain Forest and Range Experiment Station, p. 315-320.
Provencher, L., Forbisa, T.A., Frid, L., and Medlynd, G., 2007, Comparing alternative management strategies of fire, grazing, and weed control using spatial modeling: Ecological Modelling, v. 209, p. 249-263.

Rosenzweig, C., Casassa, G., Karoly, D.J., Imeson, A., Liu, C., Menzel, A., Rawlins, S., Root, T.L., Seguin, B., and Tryjanowski, P., 2007, Assessment of observed changes and responses in natural and managed systems. Climate change 2007-impacts, adaptation and vulnerability. Contribution of Working Group II to the Fourth Assessment Report of the Intergovernmental Panel on Climate Change, Parry, M.L., Canziani, O.F., Palutikof, J.P., van der Linden, P.J., and Hanson, C.E., eds.: Cambridge, U.K., Cambridge University Press, p. 79-131.

Schoenholtz, S.H., James, J.P., Kaminski, R.M., Leopold, B.D., and Ezell, A.W., 2001, Afforestation of bottomland hardwoods in the lower Mississippi Alluvial Valley-status and trends: Wetlands, v. 21, p. 602-613.

Starfield, A.M., 1997, A pragmatic approach to modeling for wildlife management: Journal of Wildlife Management, v. 61, p. 261-270.

Sundquist, E., Burruss, R., Faulkner, S., Gleason, R., Harden, J., Kharaka, Y., Tieszen, L., and Waldrop, M., 2008, Carbon sequestration to mitigate climate change: U.S. Geological Survey Fact Sheet 2008-2037.

For more information, contact

Stephen P. Faulkner

U.S. Geological Survey

Leetown Science Center

11649 Leetown Rd.

Kearneysville, WV 25430

304-724-4471

faulkners@usgs.gov 